\title{
O PODER REGULATÓRIO DOS ESTADOS E A PROTEÇÃO DOS INVESTIMENTOS ESTRANGEIROS: O CASO URUGUAI VERSUS PHILIP MORRIS
}

\author{
Gabriela Galiza e Silva* \\ Igor Matheus Gomes Ferreira**
}

\begin{abstract}
RESUMO: O artigo pretende analisar a regulamentação dos investimentos estrangeiros traçada por meio de Tratados Bilaterais sobre Investimentos e o impacto sobre o policy space dos Estados, notadamente no que concerne à possibilidade de indenização do investidor em caso de expropriação indireta. A metodologia aplicada consistiu na pesquisa bibliográfica e documental e a análise da decisão arbitral proferida no caso envolvendo a Philip Morris, uma das maiores empresas multinacionais produtoras de tabaco e seus derivados do mundo, e o Uruguai, no Centro Internacional para Resolução de Controvérsias sobre Investimentos (CIRDI), em razão de medidas antitabagistas adotadas pelo governo Uruguaio.
\end{abstract}

Palavras-chaves: Investimentos Estrangeiros. Arbitragem Internacional. Expropriação Indireta. Poder Regulatório. Direito ao Desenvolvimento.

\section{THE REGULATORY POWER OF STATES AND THE PROTECTION OF FOREIGN INVESTMENT: THE URUGUAY VERSUS PHILIP MORRIS CASE}

\begin{abstract}
This article intends to analyze the regulation of foreign investments drawn through the Bilateral Investment Treaties and the impact on the policy space of States, especially about the possibility of indemnification of the investor in case of indirect expropriation. The applied methodology consisted of the bibliographical and documentary research and the analysis of the arbitration award in the specific case involving Philip Morris, one of the largest multinational producers of tobacco and its derivatives in the world, and Uruguay, in the International Center for Settlement of Investment Disputes (ICSID), due to anti-smoking measures adopted by the Uruguayan government.
\end{abstract}

Key-words: Foreign Investments. International Arbitration. Indirect Expropriation. Regulatory Power. Right to Development.

\footnotetext{
* Mestranda em Direito Constitucional pela Universidade Federal do Rio Grande do Norte - UFRN; Membro do Núcleo de Pesquisa em Direito Internacional - NUPEDI/UFRN. E-mail: gabrielagaliza.adv@gmail.com.

${ }^{* *}$ Mestrando em Direito Constitucional pela Universidade Federal do Rio Grande do Norte - UFRN; Membro do Núcleo de Pesquisa em Direito Internacional - NUPEDI/UFRN. E-mail: igormatheusgf@hotmail.com.
} 


\section{INTRODUÇÃO}

O interesse em externar uma postura receptiva e protetiva aos investimentos estrangeiros, por meio da assinatura de Tratados Bilaterais sobre Investimentos (TIBs), tem como fundamento a promoção do desenvolvimento econômico dos países, na medida em que o ingresso desses investimentos no território do Estado hospedeiro contribui para o equilíbrio de sua balança de pagamentos, além de fomentar a criação de novos empregos, o crescimento da produtividade interna e a expansão tecnológica.

Os TIBs estabelecem um ambiente mais seguro para os investidores, mitigando os riscos políticos envolvidos em suas operações, principalmente no que concerne à expropriação do patrimônio investido, pois, se por um lado o direito internacional resguarda o poder expropriatório dos Estados, é certo que impõe como regra a justa compensação do particular. Questão polêmica, e que se encontra no cerne do caso concreto analisado no presente estudo, diz respeito à possibilidade de os investidores estrangeiros serem indenizados quando o prejuízo suportado não decorre propriamente da perda de sua propriedade, mas de medidas políticas adotadas pelos Estados receptores que geram um impacto negativo sobre os investimentos.

Partindo da análise das normas protetivas asseguradas aos investidores estrangeiros pelos TIBs e dos procedimentos levados a cabo pela arbitragem internacional como mecanismo de solução de controvérsias sobre investimentos, a pesquisa pretende responder se a compensação ou indenização do particular se afeiçoa como medida de justiça quando uma política regulatória adotada pelo país receptor, com amparo no interesse público, resultar em prejuízos aos interesses privados dos investidores.

O objeto em estudo está restrito ao fluxo bilateral de investimentos estrangeiros diretos, quando a transferência de ativos, tangíveis ou intangíveis, entre dois países, ocorre sob o controle total ou parcial do investidor. Não abarca, portanto, os investimentos de portfólio, também designados investimentos financeiros ou indiretos. O cerne da distinção entre as duas espécies de investimentos consiste justamente na possibilidade de controle que existe para o investidor estrangeiro direto e que se mostra ausente para o investidor estrangeiro indireto (FONSECA, 2008, P. 36). Além disso, o investimento direto tem como pano de fundo uma relação econômica durável, enquanto o investimento de portfólio visa lucrar com a valorização dos capitais e bens investidos no mercado (DIAS, 2010, p. 40), sendo, por esse motivo, mais volátil e menos representativo dos ganhos sociais de longo prazo.

A possibilidade de solução de controvérsias investidor-Estado por meio de uma corte arbitral internacional é comumente prevista nos TIBs. No decorrer do presente trabalho, será analisada a decisão proferida pelo Centro Internacional para a Arbitragem de Disputas sobre Investimentos (CIRDI) no caso Philip Morris versus Uruguai. Na ocasião, a multinacional Philip Morris, baseada em um tratado bilateral de investimento firmado entre o Uruguai e a Suíça (TBI Suíça-Uruguai), ingressou com uma ação no âmbito do CIRDI alegando prejuízos sofridos em decorrência de medidas antitabagista adotadas pelo governo Uruguaio. Trata-se de um julgamento 


\section{O PODER REGULATÓRIO DOS ESTADOS E A PROTEÇÃO DOS INVESTIMENTOS ESTRANGEIROS: O CASO URUGUAI VERSUS PHILIP MORRIS}

histórico, que colocou em evidência a promoção do interesse público à saúde frente à proteção do investidor estrangeiro garantida por um TBI.

Dessa forma, o estudo aborda o contexto que levou ao ingresso da ação por parte da empresa multinacional, os argumentos das partes na defesa de seus interesses, a decisão proferida pelos julgadores e a repercussão do caso, a fim de demonstrar que a segurança adquirida pelo investidor por meio de um tratado bilateral de investimento não é absoluta.

\section{A REGULAMENTAÇÃO INTERNACIONAL DOS INVESTIMENTOS ESTRANGEIROS}

Os Estados podem celebrar diferentes formas de tratados sobre investimentos estrangeiros, com eficácia e extensão diversificadas, mas que se assemelham quanto ao objetivo pretendido, que é o de atrair esses recursos para os seus territórios, sinalizando uma pré-disposição em recebê-los (FONSECA, 2008, p. 32).

Há esforços multilaterais para criação de um quadro regulatório abrangente para os investimentos estrangeiros, a exemplo daqueles empenhados na consolidação de um Acordo sobre Medidas de Investimentos Relacionados ao Comércio (TRIMS), no âmbito da Organização Mundial do Comércio (OMC). No entanto, as negociações multilaterais sobre investimentos ainda não lograram resultados significativos, sobretudo, em razão das dificuldades de negociação enfrentadas por países com níveis de desenvolvimento e interesses distintos (DIAS, 2010, p. 68).

Por outro lado, tratativas de regulamentação dos investimentos a nível regional têm se revelado prósperas. O Tratado de Roma de 1957, que criou a Comunidade Europeia, foi o primeiro acordo de integração econômica sobre investimento já firmado, voltado à liberalização do comércio entre os seus países (FONSECA, 2008, p. 52). Em seu esteio, inúmeros acordos foram celebrados entre países pertencentes a organizações regionais e seus parceiros comerciais. No âmbito do MERCOSUL, servem de exemplo o Protocolo de Colônia, de 17 de janeiro de 1994, que trata da promoção e proteção recíproca de investimentos entre os seus membros, e o Acordo de Cooperação Comercial e de Investimento e Plano de Ação entre o Canadá e o MERCOSUL, assinado em 16 de junho de 1998.

Contudo, a principal fonte de regulamentação dos investimentos estrangeiros permanece sendo os Tratados Bilaterais sobre Investimentos (TIBs). Segundo dados da Conferência das Nações Unidas sobre Comércio e Desenvolvimento (UNCTAD), há 2.573 TIBs assinados no mundo, dos quais 2.363 estão em vigor ${ }^{1}$. Os TIBs regem o tratamento conferido ao investidor de um Estado Parte que investe no território do outro Estado Parte,

\footnotetext{
${ }^{1}$ Segundo dados disponíveis em: http://investmentpolicyhub.unctad.org/IIA.
} 
estipulando cláusulas específicas de proteção com o fito de estabelecer um ambiente mais seguro para os investimentos.

Não obstante a sua multiplicação, esses tratados mantêm uma estrutura muito semelhante: definem investimento e investidor, estipulam regras para admissão e estabelecimento dos investimentos nos países hospedeiros, assegurando um padrão de proteção internacional, e preveem mecanismos para a solução de controvérsias (MOROSINI; XAVIER JÚNIOR, 2015, p. 423).

\subsection{STANDARDS DE PROTEÇÃO DOS INVESTIMENTOS ESTRANGEIROS}

Em regra, a celebração de tratados bilaterais sobre investimentos se dá entre um país exportador de capital (desenvolvido), que age pelo interesse de proteger os seus investidores nacionais, e um país importador de capital (em desenvolvimento), que pretende atrair novos investimentos estrangeiros para os seus territórios. Dessa forma, embora estabeleçam obrigações e direitos para os Estados Partes, esses acordos acabam beneficiando principalmente os investidores, sendo cabível falar em uma relação "trilateral” entre o Estado receptor, o Estado exportador e o investidor estrangeiro (FONSECA, 2008, p. 57).

Os diversos interesses envolvidos no processo de negociação e assinatura dos TIBs fizeram com que países desenvolvidos e subdesenvolvidos adotassem abordagens próprias. Fonseca (2008, p. 61) assinala, por exemplo, que enquanto o modelo europeu é mais restritivo e voltado à proteção dos investimentos, o modelo estadunidense e canadense é mais abrangente, atuando também na defesa da liberalização dos investimentos. O modelo Sul-Sul segue a tendência do europeu com algumas limitações concernentes à proibição de requisitos de desempenho e limitando as exigências de transparência na fase de pós-estabelecimento dos investimentos.

Inobstante algumas diferenças de conteúdo e estrutura, os TIBs adotam disposições uniformes que buscam "garantir aos investidores dos países signatários tratamento não-discriminatório, pagamento de indenização em caso de expropriação, e mecanismos de solução de controvérsias fora do quadro judiciário do Estado” (MAGALHÃES, 1997, p.13). Para Schill (2008, p. 7), essas semelhanças impressionam em razão da reconhecida flexibilização das relações internacionais bilaterais, que objetivam suprir as necessidades e as particularidades específicas dos países envolvidos.

Os standards, como são conhecidas as medidas destinadas à proteção dos investimentos, estão presentes em praticamente todos os tratados bilaterais e consistem um padrão de tratamento que deve ser assegurado aos investimentos estrangeiros como forma de minimizar os riscos políticos envolvidos em suas operações (DIAS, 2010, p. 113).

Nesse cenário, as cláusulas do tratamento nacional e da nação mais favorecida materializam o princípio da não discriminação. Aos Estados é imposto o dever de não tratar o investidor estrangeiro de forma discriminatória, assegurando-lhe o mesmo tratamento atribuído ao investidor nacional ou ao investidor de uma nação terceira.

De início, houve divergência quanto à aceitação da cláusula do tratamento nacional, defendida por países importadores de capital, sobretudo os latinoamericanos, mas rechaçada 


\section{O PODER REGULATÓRIO DOS ESTADOS E A PROTEÇÃO DOS INVESTIMENTOS ESTRANGEIROS: O CASO URUGUAI VERSUS PHILIP MORRIS}

por países exportadores de capital, favoráveis a uma maior proteção dos investimentos estrangeiros. Atualmente, o tratamento nacional é considerado vantajoso também sob o prisma dos países desenvolvidos, uma vez que o seu conteúdo normativo tem sido interpretado de modo a obstar que requisitos de desempenho (como as cotas de exportação ou de compras locais) sejam imputados aos investidores estrangeiros sem que haja uma correspondência com relação aos investidores locais (SORNARAJAH, 2004, p. 234).

Por vezes, as cláusulas do tratamento nacional e da nação mais favorecida podem se revelar insuficientes para a proteção dos investimentos estrangeiros, por possuírem conteúdo relativo, ou seja, variável “de acordo com a legislação nacional e com o tratamento concedido a estrangeiros de outros Estados” (FONSECA, 2008, p. 110). Daí ser comum a inclusão da cláusula do tratamento justo e equitativo, que permanece, contudo, "marcada pela incerteza quanto ao seu significado” (FONSECA, 2008, p; 110). Em que pese as interpretações possíveis, essa regra tem sido estudada, em seu caráter literal, como um mecanismo que visa assegurar um tratamento com justiça e equidade, em conformidade com a interpretação do direito internacional, traduzindo-se em um padrão mínimo de proteção.

Os TIBs também costumam estipular cláusulas que garantem a livre transferência dos investimentos estrangeiros, mormente no que se refere à repatriação de seus lucros. Não se trata, todavia, de um direito absoluto. Quando as circunstâncias financeiras revelarem uma dificuldade extrema na balança de pagamento, os Estados hospedeiros poderão suspender temporariamente essas transferências (SORNARAJAH, 2004, p. 239).

Em caso de expropriação dos investimentos estrangeiros, é assegurada uma justa indenização aos investidores. Entretanto, revela-se controvertida a possibilidade de compensação quando não há transferência formal do título de propriedade, mas redução do valor econômico do investimento ou perda de controle pelo investidor, em decorrência de novas políticas adotadas pelo Estado. Trata-se de hipótese conhecida como expropriação indireta ou indireta (FERNANDES; FIORARI, 2015, p. 265), inserida como contraponto ao poder regulatório dos Estados, devendo-se perquirir sobre o cabimento de indenização de um particular em razão da adoção de uma medida regulatória de interesse público. É o que se busca aprofundar nas linhas seguintes.

\subsection{EXPROPRIAÇÃO INDIRETA E O PODER REGULATÓRIO DOS ESTADOS}


O direito internacional tem como finalidade precípua a coexistência pacífica entre os Estados soberanos e iguais, atuando para promover a cooperação entre eles. Para tanto, preserva a soberania territorial, assegurando, por conseguinte, o poder expropriatório dos Estados com relação a bens nacionais e estrangeiros situados em seu território. Porém, não se trata de assegurar um poder absoluto, pois é pacífico que a expropriação esbarra em limites consagrados pelo próprio direito internacional com o intuito de salvaguardar o direito de propriedade dos investidores estrangeiros.

Requisitos como o interesse público, a proibição de tratamento discriminatório e a observância do devido processo legal costumam ser estabelecidos nos TIBs para que a expropriação não configure um ato ilegal dos Estados. A compensação dos investidores não é interpretada apenas como uma questão de direito, mas também de equidade, estando assegurada por regras convencionais, pelo costume internacional e pelos princípios gerais de direito (DIAS, 2010, p. 119).

Tribunais arbitrais internacionais têm afirmado o direito à indenização dos investidores também nos casos em que a expropriação de seus bens ocorre de maneira indireta, inclusive em decorrência dos lucros cessantes, ou seja, quando a adoção de uma medida regulatória estatal frustra a mera expectativa de lucro do investidor. Para Dias (2010, p. 120), “a indenização por lucros cessantes somente se justifica nos casos em que o Estado autoriza o investimento (ou compromete-se a não expropriar) por prazo certo, e esse prazo deixa de ser observado”, nos demais casos, prossegue a autora, “o cálculo dos lucros cessantes seria de difícil aferição, além de ocasionar o congelamento das regras e políticas internas dos Estados receptores de investimentos".

A definição ampla de expropriação indireta consagrada pelos TIBs tem sido objeto de questionamento e preocupação por parte dos países em desenvolvimento. A medida, que se volta para "a proteção do investidor em detrimento do policy space do país hospedeiro" (MOROSINI; XAVIER JÚNIOR, 2015, p. 441), nem sempre “é compensada pelas oportunidades de investimento geradas” (MOROSINI; XAVIER JÚNIOR, 2015, p. 441).

Com efeito, quando constatado que a perda gradativa do direito de propriedade do investidor advém da interferência indevida do ente público na gestão da empresa (p. ex. adoção de uma tributação arbitrária e discriminatória), a compensação do investidor se impõe como medida de justiça, portanto, verificada a denominada expropriação indireta. 


\section{O PODER REGULATÓRIO DOS ESTADOS E A PROTEÇÃO DOS INVESTIMENTOS ESTRANGEIROS: O CASO URUGUAI VERSUS PHILIP MORRIS}

Todavia, outras circunstâncias se fazem presentes quando o Estado, no exercício de seu poder de polícia (regulatório), adota uma política pública de meio ambiente, de saúde, de cultura ou de proteção aos direitos do consumidor e do trabalhador que impactam negativamente sobre os investimentos localizados em seu território. Nessa conjuntura, torna-se defensável que a finalidade de atender ao interesse público justifica a adoção das medidas regulatórias, e o sacrifício do interesse privado deve ceder ao benefício do interesse coletivo (DIAS, 2010, p. 122), afastando o dever de indenizar o investidor. Outra interpretação não se pode retirar dos princípios da supremacia e da indisponibilidade do interesse público.

Essa distinção se justifica pela necessidade de assegurar aos países receptores de capital estrangeiro o direito ao desenvolvimento, consoante reconhecido na Declaração sobre o Direito ao Desenvolvimento, adotada pela Resolução n. 41/128 da Assembleia Geral das Nações Unidas ${ }^{2}$. Nos termos consagrados pelo referido instrumento, o direito humano ao desenvolvimento implica a plena realização do direito de autodeterminação dos povos, nele incluído o exercício do direito inalienável de soberania sobre suas riquezas e recursos naturais (artigo 1.2). Os Estados devem perseguir “o constante aprimoramento do bem-estar de toda a população e de todos os indivíduos”, com base no reconhecimento do direito e do dever de formular políticas nacionais adequadas para o desenvolvimento (artigo 2.3).

Inobstante os compromissos internacionais assumidos pelos membros das Nações Unidas, a eficácia do direito ao desenvolvimento permanece problemática. As dificuldades de negociação enfrentadas por países heterogêneos obstam a adoção de instrumentos mais constringentes, implicando em uma incorporação apenas parcial de seus princípios norteadores ao direito positivo internacional. Constata-se, ante a falta de uma maior vinculação e concretude normativa, que o direito internacional do desenvolvimento ainda se encontra bastante circunscrito ao fenômeno da soft law (NASSER, 2005, p. 213-216). A fragilidade ou incipiência da proteção conferida pelo direito internacional ao desenvolvimento dos países hospedeiros fica evidente quando comparada aos standards assegurados, com força vinculativa, aos investimentos estrangeiros pelos TIBs.

Ao condicionar de forma abrangente a expropriação dos investimentos ao pagamento de indenizações, os TIBs conferem aos investidores a faculdade de demandar diretamente em tribunais arbitrais internacionais independentemente da proteção diplomática, ou seja, sem a necessidade de intervenção de seu país de origem (DIAS, 2005, p. 259-260). Expressões

\footnotetext{
2 Texto disponível em: <http://www.un.org/documents/ga/res/41/a41r128.htm>. Acesso em: 25 set. 2017.
} 
genéricas, como “medidas equivalentes à expropriação”, são comumente consagradas nos TIBs, não se distinguindo entre expropriação indireta e medidas estatais regulatórias.

Essa proteção abrangente, a priori, impossibilita que a finalidade da medida regulatória adotada sirva como justificativa para exclusão do dever de indenizar do Estado (DIAS, 2010, p. 122), provocando, em última análise, o engessamento de seu policy space. Os tribunais arbitrais internacionais instaurados para solucionar controvérsias sobre investimentos devem, então, trazer a questão da equidade para o centro de sua apreciação. A realização da justiça no caso concreto pode ensejar a aplicação de normas costumeiras ou de soft law, a princípio não vinculantes, em detrimento das cláusulas rígidas convencionadas nos TIBs.

\section{A ARBITRAGEM INTERNACIONAL PARA SOLUCIONAR CONTROVÉRSIAS SOBRE INVESTIMENTOS: O CASO URUGUAI VS. PHILIP MORRIS}

A arbitragem é uma solução pacífica de controvérsias que pode ocorrer entre Estados, também conhecida como arbitragem internacional interestatal, ou entre organizações internacionais, Estados e pessoas privadas, chamada de arbitragem mista. A concretização desse modelo de lide é possível por meio de um compromisso arbitral, que é o ato jurídico onde as partes interessadas submetem determinado litígio internacional e se obrigam a acatar o que for decidido pelos árbitros (MAZZUOLI, 2013, p. 1112). Tal procedimento pode ocorrer através de tratados quadros, sejam eles bilaterais ou multilaterais (CARREAU; BICHARA, 2016, p. 748).

A despeito de existirem várias instâncias consideradas pelos acordos internacionais para resolver controvérsias em âmbito internacional (ALONZO, 2013, p. 52), os tratados bilaterais de investimentos firmados pelos Estados da América do Sul estabelecem, em sua maioria, o Centro Internacional para Resolução de Controvérsias sobre Investimentos (CIRDI) como órgão de solução de arbitragens (VILIZZIO, 2015, p. 239).

O CIRDI foi criado pela Convenção para Resolução de Disputas Relativas a Investimentos entre Estados e Nacionais de Outros Estados, de 18 de março de 1965 (também conhecida como Convenção de Washington), e dotado de poderes para solucionar disputas que tenham origem, exclusivamente, em contratos Estaduais, característica que o diferencia de instituições arbitrais privadas não especializadas, que, muitas vezes, atribuem a si, sem base teórica ou legal, os poderes que o CIRDI possui (SORNARAJAH, 2004, p. 413-414). 


\section{O PODER REGULATÓRIO DOS ESTADOS E A PROTEÇÃO DOS INVESTIMENTOS ESTRANGEIROS: O CASO URUGUAI VERSUS PHILIP MORRIS}

A competência do referido Centro pode ser verificada no art. 25 da Convenção de Washington $^{3}$, onde se estabelece que, para o proferimento de uma decisão, é necessária a existência de uma controvérsia jurídica diretamente decorrente de um investimento entre o Estado contratante e um nacional de outro Estado contratante. Desse modo, trata-se da realização de uma arbitragem mista entre o Estado e um investidor, em função da realização de um investimento.

O direito processual que dá ao investidor a possibilidade de instaurar uma arbitragem diretamente contra o país hospedeiro é uma inovação, visto que, anteriormente, na hipótese de um litígio contra o Estado, era necessário que o investidor, além de esgotar os recursos internos do território em que os investimentos eram realizados, convencesse seu próprio governo para que lhe concedesse proteção diplomática (BORJA).

A Convenção foi concebida com o objetivo de introduzir um processo revolucionário no qual os Estados poderiam atrair melhores investimentos por meio do consentimento em garantir aos investidores certos padrões de tratamento reconhecidos pela legislação internacional e concordando, antecipadamente, que os investidores poderiam apresentar diretamente a um tribunal arbitral neutro suas reclamações quanto às violações cometidas pelo Estado hospedeiro (KALICKI; MEDEIROS, 2007, p. 60).

Contudo, o CIRDI tem demonstrado que a segurança que o investidor adquire por meio de um tratado bilateral de investimento não é absoluta. Existem prerrogativas dos Estados que são tidas como prioritárias em relação a um investimento, como na hipótese de proteção de um direito fundamental. Dentre essas circunstâncias, destaca-se a proteção à saúde da população, abordada no caso concreto a seguir.

\subsection{O CASO URUGUAI VS. PHILIP MORRIS}

Estima-se que, durante o século XX, cem milhões de pessoas faleceram devido ao consumo de tabaco, a maioria em países desenvolvidos e em antigas economias socialistas (IGLESIAS, 2007, p. 3). Em 2003, reconhecendo o tabagismo como um problema global e seriamente preocupados com o aumento do consumo e da

\footnotetext{
${ }^{3}$ Art. 25 (1) The jurisdiction of the Centre shall extend to any legal dispute arising directly out of an investment, between a Contracting State (or any constituent subdivision or agency of a Contracting State designated to the Centre by that State) and a national of another Contracting State, which the parties to the dispute consent in writing to submit to the Centre. When the parties have given their consent, no party may withdraw its consent unilaterally. Disponível em: <https://icsid.worldbank.org/en/Pages/icsiddocs/ICSID-Convention.aspx> Acesso em: 25 set. 2017.
} 
produção mundial de cigarros, particularmente nos países em desenvolvimento, os países membros das nações unidas adotaram a Convenção-Quadro para o Controle do Tabaco (CQCT) ${ }^{4}$, durante a 56ª Assembleia Mundial da Saúde.

A Convenção teve como objetivo proteger as gerações presentes e futuras das devastadores consequências ambientais, sociais, sanitárias e econômicas originárias do consumo de cigarro e da exposição à fumaça do tabaco, proporcionando uma referência para medidas antitabagistas a serem implementadas pelas partes em níveis nacional, regional e internacional, tendo como fim a redução de maneira contínua e substancial da prevalência do consumo e da exposição à fumaça do tabaco.

Ciente que o tabagismo é um problema que atinge uma parcela considerável do país, o Uruguai assinou a CQCT em 19 de junho de 2003, ratificando o referido instrumento em 9 de setembro de 2004, sendo o primeiro Estado latinoamericano a aderir à Convenção, que entrou em vigor em 2005. Com as eleições presidenciais no país, Tabaré Vázques assume a presidência em março de 2005 e, ao longo do seu governo, inicia uma série de medidas de combate ao tabagismo. Dentre essas medidas, destaca-se a obrigatoriedade de uma apresentação única das marcas de cigarro e o aumento da área de embalagem destinada a informações de saúde, que passaram a ocupar 80\% (oitenta por cento) de ambos os lados, conhecida como regulamento 80/80 (ICSID, Case No. ARB/10/7, Para. 9).

O requisito da apresentação única foi implementado através da Portaria 514, de 18 de agosto de 2008, do Ministério da Saúde Pública do Uruguai ${ }^{5}$. Em consonância com o art. 3 do citado ato normativo, as marcas comerciais de produtos de tabaco deverão possuir uma única apresentação, ficando proibido o uso de termos, elementos descritivos, sinais figurativos, dentre outras formas que tenham o efeito direto ou indireto de criar a falsa impressão, nos consumidores, de que um determinado produto derivado do tabaco é menos nocivo do que outros.

Antes da implementação da norma, era comum o uso de termos como light ou ultra light em embalagens de cigarro, onde se transmitia a ideia equivocada de que aquele item poderia ser consumido sem que o usuário necessitasse se preocupar com as consequências para sua saúde (ICSID, Case No. ARB/10/7, Para. 13).

O aumento da área destinada aos avisos de saúde em embalagens de cigarro foi implementado por meio do Decreto Presidencial no 287, de 15 de junho de $2009^{6}$. Segundo o art. $1^{\circ}$ da norma, as advertências relativas aos prejuízos que os derivados do tabaco causam à

\footnotetext{
${ }^{4}$ Texto disponível em: <http://www.who.int/fctc/text_download/en/>. Acesso em: 25 set. 2017.

5 Texto disponível em: <https://www.tobaccocontrollaws.org/files/live/Uruguay/Uruguay\%20-\%20Ordinance\% 20No.\%20514\%20-\%20 national.pdf> Acesso em: 26 set. 2017.

${ }^{6}$ Texto disponível em: <https://www.impo.com.uy/bases/decretos/287-2009>. Acesso em: 26 set. 2017.
} 


\section{O PODER REGULATÓRIO DOS ESTADOS E A PROTEÇÃO DOS INVESTIMENTOS ESTRANGEIROS: O CASO URUGUAI VERSUS PHILIP MORRIS}

saúde deverão ocupar 80\% (oitenta por cento) de ambos os lados dos pacotes de cigarro. Assim, são deixados $20 \%$ da área do produto para a marca, logotipo e outras informações.

Sentindo-se prejudicada pelas medidas adotadas, a Philip Morris, empresa multinacional produtora de tabaco e seus derivados, submete uma disputa contra o Uruguai no âmbito do CIRDI, utilizando-se de um tratado bilateral de proteção e promoção de investimentos realizado entre o Uruguai e a Suíça (TBI Suíça-Uruguai), em vigor desde 22 de abril de $1991^{7}$. A competência do Centro para julgar a ação decorre do art. 10 do referido tratado bilateral, onde se possibilita que o investidor recorra a uma corte arbitral para decidir sobre o litígio em todos os seus aspectos.

Na ação, a Philip Morris argumentou que o requisito da apresentação única, implementado pela Portaria 514, impediu que a empresa vendesse toda a sua variedade de produtos. Antes da norma, a empresa vendia diversas variantes em cada uma de suas marcas, a exemplo da Marlboro Red, Marlboro Gold, Marlboro Blue, dentre outras. Com a determinação legal, o requisitante apenas pode vender uma das variantes por marca, o que teria impactado substancialmente o valor da empresa (ICSID, Case No. ARB/10/7, Para. 10).

Além disso, também se argumentou que o Regulamento 80/80, implementado pelo Decreto 287, limitaria injustamente o direito da empresa de usar marcas comerciais legalmente protegidas, impedindo, por consequência, o seu uso adequado. A medida, segundo os requerentes, teria causado uma privação dos direitos de propriedade intelectual da Philip Morris, reduzindo ainda mais o seu valor de investimento (ICSID, Case No. ARB/10/7, Para. 11).

A empresa sustentou que as normas adotadas pelo Uruguai desrespeitaram dispositivos do TBI Suíça-Uruguai, tais como aquelas previstas no art. $3^{\circ}, \S 1^{\circ}$ (prejuízo de uso e gozo de investimento), no art. $3^{\circ}$, $\S 2^{\circ}$ (tratamento justo e equitativo), no art. $5^{\circ}$ (expropriação) e no art. 11 (observância dos compromissos). As alegações da Philip Morris apontavam que a violação de sua marca e das regulamentações do acordo de investimento teria impactado negativamente suas expectativas de lucro, configurando, por conseguinte, uma forma de expropriação de seus investimentos (MENEZES; BORGES, 2017, p. 7).

Com isso, a empresa solicitou ao tribunal que determinasse que o Uruguai eliminasse as regulamentações contestadas ou impedisse que o reclamado as utilizasse em desfavor do

\footnotetext{
7 Texto disponível em: <https://www.italaw.com/sites/default/files/laws/italaw6239.pdf>. Acesso em: 26 set. 2017.
} 
requerente ou, alternativamente, indenizasse a Philip Morris em 22,267 (vinte e dois, duzentos e sessenta e sete) milhões de dólares americanos, acrescido de juros compostos a partir da data da infração até a data da decisão. Em adição, o requerente pediu que o Estado pagasse todas as taxas e despesas, incluindo honorários advocatícios, que tivessem conexão com a arbitragem (ICSID, Case No. ARB/10/7, Para. 12).

Do outro lado da disputa, o Uruguai argumentou que as medidas utilizadas no combate ao uso do tabaco foram adotadas em conformidade com as obrigações internacionais do Estado, incluindo o TBI, com único objetivo de proteger a saúde de sua população. O país defendeu que os regulamentos foram aplicados de forma não discriminatória a todas as empresas de tabaco e constituíam um exercício razoável e de boa-fé das prerrogativas soberanas do Estado (ICSID, Case No. ARB/10/7, Para. 13).

Segundo o governo uruguaio, a medida relativa à apresentação única foi implementada com o objetivo de impedir o marketing falso dos requerentes de que certas variantes de marcas são mais seguras do que outras (ICSID, Case No. ARB/10/7, Para. 13). Já em relação ao Regulamento 80/80, argumentou-se que foi adotado para aumentar a conscientização dos consumidores sobre os riscos do consumo de tabaco para a saúde e para encorajar as pessoas a não fumarem, sendo deixado espaço suficiente para marcas e logotipos (ICSID, Case No. ARB/10/7, Para. 13).

Para o demandado, tratou-se de proteção à saúde pública e não de interferência indevida nos investimentos estrangeiros. Por conseguinte, as medidas não poderiam ser consideradas como expropriatórias, uma vez que se tratava do exercício da soberania do Estado para proteger a saúde pública dos seus cidadãos (MENEZES; BORGES, 2017, p. 8). Desse modo, o Uruguai defendeu a rejeição da totalidade dos pedidos dos requerentes e exigiu a compensação por todas as despesas e custos associados à defesa contra essas reivindicações (ICSID, Case No. ARB/10/7, Para. 14).

Em sua análise, o tribunal entendeu que todas as medidas legais realizadas internamente pelo Uruguai para a implementação do controle do tabagismo foram expressamente adotadas pela Convenção-Quadro para o Controle do Tabaco (ICSID, Case No. ARB/10/7, Para. 395). Segundo a decisão, ambas as medidas adotadas pelo Estado apresentavam o propósito de garantir a proteção à saúde da população (ICSID, Case No. ARB/10/7, Para. 391). Além disso, os árbitros entenderam que a responsabilidade quanto à adoção de medidas de saúde pública recai sobre o governo. Segundo os julgadores, os tribunais 


\section{O PODER REGULATÓRIO DOS ESTADOS E A PROTEÇÃO DOS INVESTIMENTOS ESTRANGEIROS: O CASO URUGUAI VERSUS PHILIP MORRIS}

de investimentos devem ter uma grande consideração pelas decisões governamentais em questões que envolvem as necessidades nacionais, como a proteção da saúde pública (ICSID, Case No. ARB/10/7, Para. 399).

O tribunal decidiu rejeitar os pedidos da Philip Morris, condenando a requerente a pagar ao Uruguai um montante de 7 (sete) milhões de dólares em função dos custos que o Estado teve com a arbitragem, sendo a empresa responsável, ainda, por todas as taxas e despesas administrativas da CIRDI e do Tribunal, devendo reembolsar o Estado por todos os montantes pagos ao Centro (ICSID, Case No. ARB/10/7, Para. 590).

A decisão tornou-se histórica ao reafirmar o direito soberano não somente do Uruguai, mas de todos os Estados, quanto à adoção de leis e regulamentos que visem garantir a proteção da saúde e regulamentação da comercialização e distribuição de produtos derivados do tabaco (MENEZES; BORGES, 2017, p. 9). Foi colocada em evidência a relação, por vezes antagônica, entre a proteção aos investimentos e a busca pela proteção a um bem jurídico considerado superior pelo Estado, no caso, o direito humano à saúde (VILIZZIO, 2016, p. 58).

O julgamento arbitral expôs o poder soberano que o Estado possui para assegurar a proteção e a promoção da saúde pública por meio da implementação de medidas que julgue adequadas para preservação desse direito (LENCUCHA, 2010, p. 853). Logo, ficou demonstrado o império de determinados valores - a exemplo do que ocorre em relação à proteção dos direitos humanos - e a sua tutela pelo Estado, mesmo que a adoção de novas políticas públicas possa acarretar prejuízos aos interesses privados dos investidores estrangeiros.

\section{CONCLUSÃO}

A regulamentação dos investimentos estrangeiros deve proteger os interesses do investidor sem deixar de resguardar as necessidades internas e prioritárias do Estado de acolhimento. Ocorre que os tratados bilaterais sobre investimentos, conforme idealizados e executados em seu modelo mais clássico, estabelecem uma proteção ampla e rígida dos investimentos, mas não garantem aos Estados hospedeiros a continuidade ou a qualidade dos investimentos atraídos para o seu território.

Em outras palavras, a redução ou engessamento do policy space não é necessariamente acompanhada por medidas de desenvolvimento apropriadas à realidade dos Estados 
hospedeiros. Nesse cenário, as políticas regulatórias estatais podem ser confrontadas pelos investidores estrangeiros em tribunais arbitrais internacionais, sob a alegação de expropriação indireta do patrimônio particular. Impõe-se, portanto, a necessidade de distinguir entre a expropriação indireta propriamente dita e as medidas que se inserem no âmbito do poder regulatório dos Estados, com o fito de enquadrar quais situações ensejam a indenização do investidor.

Em razão da amplitude conferida à expropriação indireta pelos TIBs, o desafio a ser superado pela arbitragem consiste, portanto, em sopesar o direito de propriedade dos investidores - que, assim como o poder expropriatório dos Estados, não é absoluto - com o poder regulatório dos Estados. A solução, no caso concreto, não pode atender apenas ao interesse privado, devendo salvaguardar as necessidades internas e prioritárias dos Estados receptores, permitindo a implantação de políticas voltadas ao seu desenvolvimento, com lastro na consecução do interesse público.

No caso da arbitragem internacional envolvendo o Estado do Uruguai e a empresa multinacional Philip Morris, a decisão reafirmou o poder soberano que o Estado possui para garantir a proteção e a promoção da saúde pública de sua população. Foi demonstrado que medidas de interesse público e de proteção dos direitos humanos podem ser sobrepostas a interesses particulares dos investidores, mesmo quando protegidos por tratados bilaterais constringentes. Do contrário, o desenvolvimento que se almeja alcançar pelo ingresso dos investimentos estrangeiros ficaria prejudicado pela ausência de políticas públicas adequadas.

\section{REFERÊNCIAS}

Agreement Between the Swiss Confederation and the Oriental Republic of Uruguay on the Reciprocal Promotion and Protection of Investments. Berna, 7 out. 1988. Disponível em: <https://www.italaw.com/sites/default/files/laws/italaw6239.pdf>. Acesso em: 26 set. 2017.

ALONSO, José Fernández. Controvérsias entre Estados e Investidores Transnacionais: Reflexões sobre o Acúmulo de Casos Contra a República Argentina. Revista Tempo do Mundo, Brasília, v. 5, n. 1, p. 45-88, abr. 2013.

BORJA, Ana Gerdau de. Arbitragens de Investimento e o caso do Brasil. Disponível em: <http://www.britcham.com.br/email/resenha_legal_0910.htm>. Acesso em: 24 set. 2017. 


\section{O PODER REGULATÓRIO DOS ESTADOS E A PROTEÇÃO DOS INVESTIMENTOS ESTRANGEIROS: 0 CASO URUGUAI VERSUS PHILIP MORRIS}

CARREAU, Dominique; BICHARA, Jahyr Philippe. Direito Internacional Econômico. 2. ed. Rio de Janeiro: Lumen Juris, 2016.

DIAS, Bernadete de Figueiredo. A abordagem do Direito ao Desenvolvimento: seu Papel na Implementação do Direito ao Desenvolvimento. In: AMARAL JÚNIOR, Alberto do et al (Org.). Direito Internacional e Desenvolvimento. São Paulo: Manole, 2005, p. 253-270.

Investimentos Estrangeiros no Brasil e o Direito Internacional. Curitiba: Juruá, 2010.

FERNANDES, Érika Capella; FIORATI, Jete Jane. Os ACFIs e os BITS assinados pelo Brasil: uma análise comparada. RIL, Brasília, v. 52, n. 208, p. 247-276, out./dez. 2015. Disponível em: <http://www2.senado.leg.br/bdsf/item/id/517706>. Acesso em: 20 maio 2017.

FONSENCA, Karla Closs. Investimentos Estrangeiros: regulamentação internacional e acordos bilaterais. Curitiba: Juruá, 2008.

ICSID. Philip Morris Brand Sàrl (Switzerland), Philip Morris Products S.A. (Switzerland) and Abal Hermanos S.A. (Uruguay) v. Oriental Republic of Uruguay (ICSID Case No. ARB/10/7). Disponível em $<$ https://icsid.worldbank.org/en/Pages/cases/casedetail.aspx?CaseNo=ARB/10/7>. Acesso em: 25 set. 2017.

ICSID Convention. Disponível em: <https://icsid.worldbank.org/en/Pages/icsiddocs/ ICSIDConvention.aspx> Acesso em: 25 set. 2017.

IGLESIAS, Roberto, et al. Tobacco control in Brazil. Health Nutrition and Population (HNP). Discussion Paper. Washington DC., 01 Ago. 2007. Disponível em: $<$ http://siteresources.worldbank.org/BRAZILEXTN/Resources/TobaccoControlinBrazilenglis hFinal.pdf>. Acesso em: 18 março 2017.

KALICKI, Jean; MEDEIROS, Suzana. Investment arbitration in Brazil: revisiting Brazil's traditional reluctance towards ICSID, BITs, and investor-state arbitration. Revista de Arbitragem e Mediação, São Paulo, v. 4, n. 14, p.57-86, jul. 2007, p. 60.

LENCUCHA, Raphael. Philip Morris versus Uruguay: health governance challenged. The Lancet, [s.l.], v. 376, n. 9744, p.852-853, set. 2010. Elsevier BV.

MAGALHÃES, José Carlos de. Acordos bilaterais de promoção e proteção de investimentos. Revista de Informação Legislativa, Brasília, v. 134, n. 34, p.13-18, abr./jul., 1997. Disponível em: $\quad$ https://www2.senado.leg.br/bdsf/bitstream/handle/id/248/r135-02.pdf? sequence=4>. Acesso em: 20 set. 2017. 
MAZZUOLI, Valerio de Oliveira. Curso de direito internacional público. 7. ed. São Paulo: Revista dos Tribunais, 2013.

MENEZES, Henrique Zeferino; BORGES, Luciana Correia. Propriedade Intelectual e Saúde Pública: Qual a Importância dos Acordos Internacionais de Investimento?. In: $9^{\circ}$ congresso latino-americano de ciência política, 2017, Montevideo. Painel Estado e investimento estrangeiro: normas e instituições no debate contemporâneo, Montevideo: ALACIP, 2017, p. 2-19.

MOROSINI, Fabio; XAVIER JÚNIOR, Ely Caetano. Regulação do investimento estrangeiro direto no Brasil: da resistência aos tratados bilaterais de investimentos à emergência de um novo modelo regulatório. Revista de Direito Internacional, Brasília, v. 12, n. 2, p. 420-447, 2015. Disponível em: <https://www.publicacoesacademicas.uniceub.br/rdi/article/view/ 3586/pdf>. Acesso em: 20 maio 2017.

NASSER, Salem Hikmat. Desenvolvimento, Costume Internacional e Soft Law. In: AMARAL JÚNIOR, Alberto do et al (Org.). Direito Internacional e Desenvolvimento. São Paulo: Manole, 2005. p. 201-218.

SCHILL, Stephan W. The multilateralization of international investiment law: the emergence of a multilateral system of investiment protection on the basis of bilateral treaties. In: Inaugural Conference of the Society of Internacional Economic Law, 2008, Geneva. SIEL Online Proceedings Working Paper $\mathbf{n}^{\mathbf{0}}$ 18/08. Geneva: Siel, 2008. Disponível em: <https://papers.ssrn.com/sol3/papers.cfm?abstract_id=1151817>. Acesso em: 20 out. 2017.

SORNARAJAH, Muthucumaraswamy. The International Law of Foreign Investiment. 2. ed. Cambridge: Cambridge University Press, 2004.

URUGUAY. Decreto-lei no 287/009, de 15 de junho de 2009. Proteccion del Derecho Al Medio Ambiente Libre de Humo de Tabaco y Su Consumo. Advertencias Sanitarias. Disponível em: <https://www.impo.com.uy/bases/decretos/287-2009>. Acesso em: 26 set. 2017.

Ordenanza $\mathrm{n}^{\circ}$ 514, de 18 de agosto de 2008. Disponível em: <https://www.tobaccocontrollaws.org/files/live/Uruguay/Uruguay\%20-\%20Ordinance\% ～20No.\%20514\%20\%20 national.pdf> Acesso em: 26 set. 2017.

VILIZZIO, Magdalena Bas. Claves del Caso Philip Morris Contra Uruguay en el Escenario Sudamericano. Informe de Coyuntura del Observatorio de Regionalismo en América Latina y el Caribe (ORALC), 2016, v. 1, p. 45-58, n. 2. Disponível em: $<$ http://www.oralc.com.uy/wp-content/uploads/informe-de-coyuntura-N\%C2\%BA2ORALC.pdf>. Acesso em: 25 set. 2017. 
Solución de controversias en los tratados bilaterales de inversión: mapa de situación en América del Sur. Revista de la Secretaría del Tribunal Permanente de Revisión, [s.l.], v. 3, n. 5, p.233-253, 26 mar. 2015.

WHO. Framework Convention on Tobacco Control. Disponível em: <http://www.who.int/fctc/text_download/en/>. Acesso em: 25 set. 2017. 